Check for updates

Cite this: RSC Adv., 2019, 9, 6027

Received 30th November 2018 Accepted 3rd February 2019

DOI: $10.1039 / \mathrm{c} 8 \mathrm{ra09850f}$

rsc.li/rsc-advances

\section{New rhodamine B-based chromo-fluorogenic probes for highly selective detection of aluminium(III) ions and their application in living cell imaging $\dagger$}

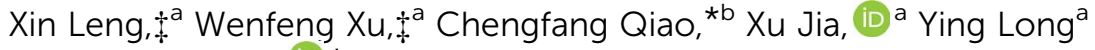 \\ and Bingqin Yang $\mathbb{D I}^{* a}$
}

Two rhodamine B-based fluorescent probes, BOS1 and BOS2, were designed and synthesized with good yields via the condensation reactions between the o-diaminobenzene modified rhodamine core structure (RBO) and salicylaldehyde derivatives. Both the probes exhibited remarkable absorbance-on and fluorescence-on responses to $\mathrm{Al}^{3+}$ over other metal ions in ethanol-water $(1: 9, \mathrm{v} / \mathrm{v})$ medium via the rhodamine ring-opening approach, which can be used for "naked-eye" $\mathrm{Al}^{3+}$ detection over a broad $\mathrm{pH}$ range (5-9). The fluorescence intensities of the probes were linear with the $\mathrm{Al}^{3+}$ ion concentration, resulting in a low limit of detection of $1.839 \mu \mathrm{M}$ (BOS1) and $1.374 \mu \mathrm{M}$ (BOS2) for $\mathrm{Al}^{3+}$. In addition, the MTT assays and cell imaging experiments of $\mathrm{Al}^{3+}$ in SGC-7901 living cells demonstrated that the probes had negligible cytotoxicity, and were cell permeable and suitable for sensing $\mathrm{Al}^{3+}$ in biological systems.

\section{Introduction}

As the most abundant metal element in the earth's crust, aluminium has been widely used in our daily life, such as in food additives, clinical drugs, kitchen utensils, packing materials, water treatment, etc. ${ }^{1-5}$ However, the heavy and inappropriate use of aluminium products in recent years has created adverse effects on life and environmental systems due to its toxicity. ${ }^{6-8}$ In particular, the excessive intake of dissolved $\mathrm{Al}^{3+}$ easily causes accumulation in the human body, which may cause several disorders, including Alzheimer's disease, osteomalacia, Parkinson's disease, and breast cancer. ${ }^{9-12}$ Therefore, the fast detection and quantitative analysis of $\mathrm{Al}^{3+}$ in the human body are crucially important for health warnings.

Because of the insufficient spectroscopic characteristics of $\mathrm{Al}^{3+}$, the reported $\mathrm{Al}^{3+}$-detection techniques, such as ${ }^{27} \mathrm{Al} \mathrm{NMR}$ technology, atomic absorption spectrometry (AAS) ${ }^{13}$ inductively coupled plasma atomic emission spectrometry (ICP-AES), ${ }^{14}$

${ }^{a}$ Key Laboratory of Synthetic and Natural Functional Molecule Chemistry of Ministry of Education, College of Chemistry and Materials Science, Northwest University, Xi'an 710127, China. E-mail: organic_lengxin@163.com

${ }^{b}$ Shaanxi Key Laboratory of Comprehensive Utilization of Tailings Resources, College of Chemical Engineering and Modern Materials, Shangluo University, Shangluo 72600o, China.E-mail: xiaoqiaoqcf@126.com

$\dagger$ Electronic supplementary information (ESI) available: Characterization data, including NMR; mass spectra; photophysical properties; IR, fluorescence and UV-vis absorption spectra; and other cytotoxicity data. See DOI: 10.1039/c8ra09850f

$\ddagger$ Both authors contributed equally. mass spectrometry and electrochemical methods,${ }^{15}$ are usually complex, time-consuming and costly. Fluorescence analysis, as a type of highly selective and sensitive detection method, not only possesses the features of easy operation, low cost, low detection limit and rapid response, but also can be used for real-time living organism detection, has attracted significant interest of researchers. ${ }^{16-20}$ Apparently, the reasonable design and preparation of effective biocompatible $\mathrm{Al}^{3+}$ fluorescent chemosensors are urgent problems need to be solved currently. ${ }^{21-24}$

Considering the weak coordination ability and strong tendency to hydrolysis of $\mathrm{Al}^{3+}$ ions, small-molecular fluorescent probes with bright chromophore and multidentate coordination sites are highly promising. Recent studies reveal that the rhodamine-based probes are regarded as ideal candidates for the "off-on" fluorescent sensors owing to the excellent photophysical properties such as remarkable photostability, high fluorescence quantum yields, special response mechanism, strong anti-interference ability and long emission wavelength..$^{25-28}$ On one hand, with the introduction of target metal ions, the rhodamine framework can display "turn-on" fluorescence signals through structural change between the spirocyclic and open-cycle forms. ${ }^{29}$ On the other hand, the free-rotating benzoic acid group can be accessibly substituted by the functional groups with multidentate chelation sites to chelate target ions for fluorescence sensor without changing the spirolactam forms. ${ }^{30}$ Particularly, the Schiff base rhodamine probes have received lots of attention due to their high sensitivity and selectivity, rapid response time and ease of synthesis, ${ }^{31,32}$ where 
the imines functional groups can be generated by the introduction of different carbonyl or amines to adjust the spectral response range of the rhodamine matrix, and at the same time to form suitable "ONO", "ONN" or "ONNO" sites to rapidly anchor the target metal ions. ${ }^{33}$ Moreover, the imines also provide the opportunity of $\mathrm{C}=\mathrm{N}$ isomerization for probes to generate richer fluorescence sensing pathway. ${ }^{34}$

Herein, two new rhodamine B-based sensors, BOS1 and BOS2 were designed and prepared by a three-step synthesis with simple raw materials (Scheme 1). The two chemosensors show highly selective and sensitive fluorescence response to $\mathrm{Al}^{3+}$ with the ring-opening sensor mechanisms described above, which can be used for naked-eye detection with rapid switch-on fluorescence and remarkable color changes. Furthermore, these advanced characteristics endow the two probes highly promising for biological imaging applications.

\section{Experimental}

\section{Materials and methods}

All chemicals were of analytical-reagent grade, and they were commercially available from commercial sources and used without further purification. The SGC-7901 living cells (human gastric carcinoma cells) were obtained from Xi'an Jiaotong University Health Science Center. The twice-distilled water was used throughout the experiment. The solid powders of probes BOS1/BOS2 were dissolved in ethanol solution in concentration of $1 \mathrm{mM}$ as stock solutions. And then took out quantificational BOS1/BOS2 in different testing systems. Fluorescence spectra were carried on a HITACHI F-4500 fluorescence spectrophotometer. UV-vis spectra were performed on a Shimadzu UV-1700 spectrophotometer. The elemental analyses of $\mathrm{C}, \mathrm{H}$, and $\mathrm{N}$ were performed on a Vario EL III elemental analyzer. IR spectra were recorded on a Bruker Tensor 27 spectrometer. NMR spectra were obtained on a Varian INOVA-400 MHz spectrometer (at 100 $\mathrm{MHz}$ for ${ }^{13} \mathrm{C}$ NMR and $400 \mathrm{MHz}$ for ${ }^{1} \mathrm{H}$ NMR). A Bruker micro
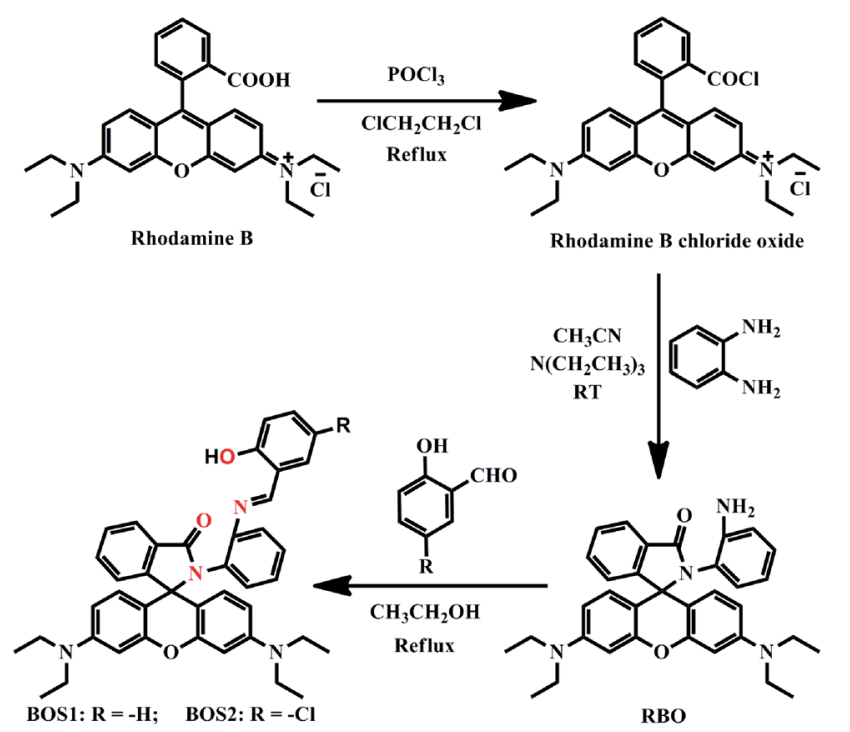

Scheme 1 Syntheses of BOS1 and BOS2.
TOF-Q II ESI-TOF LC/MS/MS Spectroscopy was used to perform mass spectra. Melting point tests were taken on an XT-4 micromelting apparatus and uncorrected. Results of cytotoxicity were analyzed with the Soft max pro software (version 2.2.1) in Spectra max190-Molecular Devices. The living cells imaging were performed on an Olympus FV1000 confocal microscopy with $\lambda_{\mathrm{ex}}=400 \mathrm{~nm}$.

\section{Synthetic procedures}

Synthesis of RBO. Phosphorus oxychloride $(1 \mathrm{~mL}, 10.09$ $\mathrm{mmol})$ was added to a dry 1,2-dichloroethane solution $(20 \mathrm{~mL})$ of rhodamine B (1.59 g, $3 \mathrm{mmol})$, and the resulting mixture was refluxed for $6 \mathrm{~h}$. After cooling to room temperature and removal of the solvent in vacuo, the crude product of rhodamine B chloride oxide was obtained without any purification. Then the residue was directly reacted with an acetonitrile solution $(30 \mathrm{~mL})$ of $o$-phenylenediamine $(0.324 \mathrm{~g}, 3 \mathrm{mmol})$ at room temperature for $30 \mathrm{~min}$, followed by addition of $2 \mathrm{~mL}$ triethylamine as acidcapturer, the mixture was stirred for $8 \mathrm{~h}$. After removal of the solvent under reduced pressure, the crude product was purified by silica gel column chromatography to give RBO in a yield of 89.3\%. HRMS (ESI) calcd for $\left(\mathrm{C}_{34} \mathrm{H}_{36} \mathrm{~N}_{4} \mathrm{O}_{2}\right) \mathrm{m} / \mathrm{z}=532.2838$, found: $533.2897(\mathrm{M}+\mathrm{H})^{+} .{ }^{1} \mathrm{H}$ NMR $\left(400 \mathrm{MHz}, \mathrm{CDCl}_{3}\right), \delta$ : 8.07$8.09(\mathrm{~d}, J=8 \mathrm{~Hz}, 1 \mathrm{H}), 7.57-7.62(\mathrm{q}, J=8 \mathrm{~Hz}, 2 \mathrm{H}), 7.29-7.31(\mathrm{~d}, J=$ $8 \mathrm{~Hz}, 1 \mathrm{H}), 6.98-7.01$ (t, $J=4 \mathrm{~Hz}, 1 \mathrm{H}), 6.80-6.08$ (m, 9H), 3.32-3.37 (dd, $J=8 \mathrm{~Hz}, 8 \mathrm{H}), 1.17-1.21(\mathrm{t}, J=8 \mathrm{~Hz}, 12 \mathrm{H})$.

Synthesis of BOS1. RBO $(0.53 \mathrm{~g}, 1 \mathrm{mmol})$ was dissolved in $20 \mathrm{~mL}$ ethanol. Then a solution of salicylaldehyde $(0.12 \mathrm{~g}, 1$ $\mathrm{mmol})$ in ethanol $(20 \mathrm{~mL})$ was added and the mixture was stirred and refluxed for $4 \mathrm{~h}$ at $80{ }^{\circ} \mathrm{C}$. After removal of the solvent under reduced pressure, the resulting precipitate was purified by silica gel column chromatography to give BOS1 (light yellow power) in $76.3 \%$ yield. Mp: $158-159{ }^{\circ} \mathrm{C}$. Anal. calcd for $\mathrm{C}_{41} \mathrm{H}_{40} \mathrm{~N}_{4} \mathrm{O}_{3}$ (\%): C, 77.33; H, 6.33; N, 8.80. Found: C, 77.28; $\mathrm{H}$, 6.36; $\mathrm{N}$, 8.91. HRMS (ESI) calcd for $\left(\mathrm{C}_{41} \mathrm{H}_{40} \mathrm{~N}_{4} \mathrm{O}_{3}\right) \mathrm{m} / \mathrm{z}=$ 636.3100, found: $659.2972(\mathrm{M}+\mathrm{Na})^{+}$. IR $(\mathrm{KBr}) \nu$ : 3444, 2968, $1699,1616,1514,1356,1223,1115,754,638 \mathrm{~cm}^{-1} \cdot{ }^{1} \mathrm{H}$ NMR $(400$ $\left.\mathrm{MHz}, \mathrm{CDCl}_{3}\right) \delta(\mathrm{ppm}): 12.50(\mathrm{~s}, 1 \mathrm{H}), 8.12-5.91(\mathrm{~m}, 18 \mathrm{H}), 5.59-$ $5.46(\mathrm{~d}, J=8 \mathrm{~Hz}, 1 \mathrm{H}), 3.39-3.20(\mathrm{dq}, J=8 \mathrm{~Hz}, 4 \mathrm{H}), 3.17-2.90(\mathrm{~d}, J$ $=8 \mathrm{~Hz}, 4 \mathrm{H}), 1.23-1.16(\mathrm{t}, J=8 \mathrm{~Hz}, 6 \mathrm{H}), 1.13-0.96(\mathrm{t}, J=8 \mathrm{~Hz}$, $6 \mathrm{H}) .{ }^{13} \mathrm{C} \mathrm{NMR}\left(100 \mathrm{MHz}, \mathrm{CDCl}_{3}\right), \delta$ (ppm): 166.1, 163.0, 161.1, $154.7,153.4,151.7,149.1,148.5,147.8,132.8,132.5,132.4$, $129.8,129.1,127.1,124.0,120.6,119.7,118.4,117.3,108.3$, 107.4, 106.3, 97.9, 97.0, 66.1, 44.6, 44.1, 12.6.

Synthesis of BOS2. RBO $(0.53 \mathrm{~g}, 1 \mathrm{mmol})$ was dissolved in $20 \mathrm{~mL}$ ethanol. Then a solution of 5-chlorosalicylaldehyde $(0.16 \mathrm{~g}, 1 \mathrm{mmol})$ in ethanol $(20 \mathrm{~mL})$ was added and the mixture was stirred and refluxed for $2 \mathrm{~h}$ at $80{ }^{\circ} \mathrm{C}$. After removal of the solvent under reduced pressure, the resulting precipitate was purified by silica gel column chromatography to give BOS2 (light yellow power) in $78.5 \%$ yield. Mp: $154-156{ }^{\circ} \mathrm{C}$. Anal. calcd for $\mathrm{C}_{41} \mathrm{H}_{39} \mathrm{~N}_{4} \mathrm{O}_{3} \mathrm{Cl}$ (\%): C, 73.36; $\mathrm{H}, 5.86 ; \mathrm{N}$, 8.35. Found: $\mathrm{C}$, 73.04; H, 5.98; N, 8.24. HRMS (ESI) calcd for $\left(\mathrm{C}_{41} \mathrm{H}_{39} \mathrm{~N}_{4} \mathrm{O}_{3} \mathrm{Cl}\right) \mathrm{m} / \mathrm{z}$ $=670.2711$, found: $671.2773(\mathrm{M}+\mathrm{H})^{+}$. IR $(\mathrm{KBr}) \nu$ : 3442, 2968, 1699, 1616, 1514, 1351, 1223, 1116, $756 \mathrm{~cm}^{-1} .{ }^{1} \mathrm{H}$ NMR (400 $\mathrm{MHz}, \mathrm{CDCl}_{3}$ ), $\delta: 12.53(\mathrm{~s}, 1 \mathrm{H}), 8.48-5.80(\mathrm{~m}, 17 \mathrm{H}), 5.55(\mathrm{~s}, 1 \mathrm{H})$, 
3.44-3.23 (m, 4H), $3.11(\mathrm{~s}, 4 \mathrm{H}), 1.23-0.98(\mathrm{~m}, 12 \mathrm{H}) .{ }^{13} \mathrm{C}$ NMR $\left(100 \mathrm{MHz}, \mathrm{CDCl}_{3}\right) \delta: 166.1,161.3,159.7,154.7,153.6,151.4$, $149.2,148.4,147.8,132.5,131.1,130.4,129.8,129.0,127.1$, 123.9, 120.6, 119.5, 118.9, 117.3, 108.4, 107.5, 106.6, 98.0, 97.0, $68.2,44.6,44.1,12.6$.

\section{Preparation of the test solution}

The $10 \mu \mathrm{M}$ stock solution of probes BOS1/BOS2 were prepared in ethanol-water $(1: 9, \mathrm{v} / \mathrm{v}$, Tris- $\mathrm{HCl}, \mathrm{pH}=7.2)$. The solutions of various testing cation species were prepared from $\mathrm{Ca}\left(\mathrm{NO}_{3}\right)_{2}$ $\cdot 4 \mathrm{H}_{2} \mathrm{O}, \mathrm{Mg}\left(\mathrm{NO}_{3}\right)_{2} \cdot 6 \mathrm{H}_{2} \mathrm{O}, \mathrm{Co}\left(\mathrm{NO}_{3}\right)_{2} \cdot 6 \mathrm{H}_{2} \mathrm{O}, \mathrm{AgNO}_{3}, \mathrm{Cd}\left(\mathrm{NO}_{3}\right)_{2}{ }^{-}$ - $4 \mathrm{H}_{2} \mathrm{O}, \mathrm{Zn}\left(\mathrm{NO}_{3}\right)_{2} \cdot 6 \mathrm{H}_{2} \mathrm{O}, \mathrm{Cu}\left(\mathrm{NO}_{3}\right)_{2} \cdot 3 \mathrm{H}_{2} \mathrm{O}, \mathrm{KNO}_{3}, \mathrm{NaNO}_{3}, \mathrm{LiNO}_{3}$, $\mathrm{Mn}\left(\mathrm{NO}_{3}\right)_{2} \cdot 4 \mathrm{H}_{2} \mathrm{O}, \mathrm{Pd}\left(\mathrm{NO}_{3}\right)_{2} \cdot 2 \mathrm{H}_{2} \mathrm{O}, \mathrm{Hg}\left(\mathrm{NO}_{3}\right)_{2} \cdot \mathrm{H}_{2} \mathrm{O}, \mathrm{Ni}\left(\mathrm{NO}_{3}\right)_{2}-$ . $6 \mathrm{H}_{2} \mathrm{O}, \quad \mathrm{Sn}\left(\mathrm{NO}_{3}\right)_{2}, \quad \mathrm{~Pb}\left(\mathrm{NO}_{3}\right)_{2}, \quad \mathrm{Cr}\left(\mathrm{NO}_{3}\right)_{3} \cdot 9 \mathrm{H}_{2} \mathrm{O}, \quad \mathrm{Ba}\left(\mathrm{NO}_{3}\right)_{2}$, $\mathrm{Al}\left(\mathrm{NO}_{3}\right)_{3} \cdot 9 \mathrm{H}_{2} \mathrm{O}$, and $\mathrm{Fe}\left(\mathrm{NO}_{3}\right)_{3} \cdot 9 \mathrm{H}_{2} \mathrm{O}$ dissolved in the double distilled water. Before spectroscopic measurements, the corresponding solutions of probes were freshly prepared by diluting the high concentration stock solutions. All the measurements were made according to the procedures as follows. Placing $1 \mathrm{~mL}$ of the probe solution and an appropriate aliquot of each metal stock into a $10 \mathrm{~mL}$ glass tube, and diluting the solution to $10 \mathrm{~mL}$ with ethanol-water $(1: 9, \mathrm{v} / \mathrm{v}$, Tris- $\mathrm{HCl}, \mathrm{pH}=7.2)$ solution.

\section{Cytotoxicity assays}

The MTT assays were performed to evaluate the toxicity of BOS1, BOS2 and $\mathrm{Al}^{3+}$ by SGC-7901 living cells. ${ }^{35}$ 90\% confluent cells were chosen, digested by $1 \mathrm{~mL} 0.25 \%$ of trypsin, and transferred in 96-well plates. The cells were treated and incubated at $37{ }^{\circ} \mathrm{C}$ under $5 \% \mathrm{CO}_{2}$ in culture medium (DMEM (Dulbecco's Modified Eagle Medium) $+10 \%$ FBS (Fetal Bovine Serum) ) and maintained $24 \mathrm{~h}$. Different concentrations of BOS1, BOS2 and $\mathrm{Al}^{3+}$ were added to the 96-well plates, respectively. Another 24 hours incubation was taken at the same condition. Following this, the medium was removed and washed three times with phosphate buffered saline (PBS). Then the medium was replaced with mixed liquor of MTT ( $5 \mathrm{mg} \mathrm{mL}^{-1}$ ) and culture medium, and incubated for an additional $4 \mathrm{~h}$. After that, the MTT was removed and washed three times with PBS. Subsequently, $150 \mu \mathrm{L}$ DMSO was carefully added to each well and ultrasonic oscillation for 10 minutes. All the experiments were conducted in triplicate. The cell viability (\%) was calculated according to the equation: cell viability $(\%)=\left[\mathrm{OD}_{490}(\right.$ sample $) / \mathrm{OD}_{490}($ control $\left.)\right] \times 100 \%$, where $\mathrm{OD}_{490}$ (sample) represents the optical density of the wells treated with various concentration of probes or metal ions and $\mathrm{OD}_{490}$ (control) represents that of the wells treated with ethanol.

\section{Cell culture and fluorescence imaging}

The SGC-7901 living cells (human gastric carcinoma cells) were cultured in DMEM replenished with $10 \%$ FBS. Before the experiments, cells were processed with probes BOS1/BOS2 (20 $\mu \mathrm{M}$ ) for $1 \mathrm{~h}$ at $37^{\circ} \mathrm{C}$ in humidified air and $5 \% \mathrm{CO}_{2}$, washed three times with PBS then imaged. After incubation with $\mathrm{Al}^{3+}(20 \mu \mathrm{M})$ for another $1.5 \mathrm{~h}$ at $37{ }^{\circ} \mathrm{C}$, cells were washed three times with PBS to remove remaining metal ions and then imaged. Confocal fluorescence imaging was carried out with an Olympus FV1000 laser scanning microscope with $80 \times$ objective lens.

\section{Results and discussion}

\section{Spectroscopic properties}

Both of the probes BOS1 and BOS2 exhibited highly selective and sensitive response to $\mathrm{Al}^{3+}$ ion in ethanol-water $(1: 9, \mathrm{v} / \mathrm{v})$. Although the different salicylaldehyde moieties had effects on the fluorescence/absorption intensities and response time, no obvious differences were observed on the other spectral properties of the two probes. Therefore, only the property of BOS1 is described in detail. The optical spectra of BOS2 are given in the ESI. $\dagger$

The fluorescence sensing ability of BOS1 toward metal ions was investigated in ethanol-water $(1: 9, \mathrm{v} / \mathrm{v}$, Tris- $\mathrm{HCl}, \mathrm{pH}=7.2)$ solution. As shown in Fig. 1a, the free BOS1 exhibited negligible fluorescence emission due to its spirolactam form. Upon the further addition of different metal ions $\left(\mathrm{Co}^{2+}, \mathrm{K}^{+}, \mathrm{Ca}^{2+}, \mathrm{Mg}^{2+}\right.$, $\mathrm{Cd}^{2+}, \mathrm{Mn}^{2+}, \mathrm{Ni}^{2+}, \mathrm{Ba}^{2+}, \mathrm{Li}^{+}, \mathrm{Na}^{+}, \mathrm{Zn}^{2+}, \mathrm{Cu}^{2+}, \mathrm{Pb}^{2+}, \mathrm{Ag}^{+}, \mathrm{Cr}^{3+}, \mathrm{Pd}^{2+}$, $\mathrm{Hg}^{2+}, \mathrm{Sn}^{2+}, \mathrm{Fe}^{3+}, \mathrm{Al}^{3+}$ ), only the $\mathrm{Al}^{3+}$ ion led to a remarkable luminescence enhancement at a maximum emission wavelength of $592 \mathrm{~nm}$, while no obvious luminescent intensity changes were observed in the presence of other metal ions. These results indicated the high selectivity of the BOS1 probe for $\mathrm{Al}^{3+}$ detection.

Fluorescence titration experiments were performed to investigate the interaction between BOS1 and $\mathrm{Al}^{3+}$ (Fig. 1b). Since the stable and characteristic "spirolactam form" of rhodamine B group, free BOS1 shows colorless and no fluorescence response in the visible region range from 480 to $660 \mathrm{~nm}$. However, along with the gradual addition of $\mathrm{Al}^{3+}$, the fluorescence emission intensity at $592 \mathrm{~nm}$ was significantly enhanced with a color variation from colorless to orange (Fig. 2), suggesting that the xanthene moiety of rhodamine $\mathrm{B}$ was subjected to the delocalization interference, and BOS1 was a true "off-on" chemosensor for $\mathrm{Al}^{3+}$. After the addition of 1.0 equiv. of $\mathrm{Al}^{3+}$, the titration curve reached a steady plateau accompanied by more than 100 -fold increase in the emission at $592 \mathrm{~nm}$ compared with that of free BOS1. Such significant enhancement of fluorescence clearly indicated that the spirolactam form of rhodamine $\mathrm{B}$ was unfolded or the rotation of the " $\mathrm{C}=\mathrm{N}$ " group were inhibited owing to gradually adding $\mathrm{Al}^{3+}$ to BOS1, and a highly delocalized $\pi$-conjugated system was ultimately formed. The association constant $K$, of BOS1 with $\mathrm{Al}^{3+}$ was calculated according to the Benesi-Hildebrand equation: ${ }^{36,37}$

$$
\left(F_{\max }-F_{0}\right) /\left(F_{\mathrm{x}}-F_{0}\right)=1+(1 / K)\left(1 /\left[\mathrm{Al}^{3+}\right]\right),
$$

where $F_{\max }, F_{0}$ and $F_{\mathrm{x}}$ are the fluorescence intensities of probe in the presence of $\mathrm{Al}^{3+}$ at saturation, free probe, and any intermediate $\mathrm{Al}^{3+}$ concentration, respectively. The binding constant value was found to be $K=4.48 \times 10^{-4} \mathrm{M}$ (for BOS2: $K=4.92 \times$ $10^{-4}$ M, Fig. S3†).

Moreover, the detection limit of BOS1 and BOS2 were determined from the result of titrating experiment. As shown in Fig. 3, according to the widely used method, ${ }^{38,39}$ linear regression curves were fitted based on the plots of $\left(F_{\min }-F_{\mathrm{x}}\right) /\left(F_{\min }-\right.$ $\left.F_{\text {max }}\right) v s . \log \left[\mathrm{Al}^{3+}\right]$, where the $F_{\mathrm{x}}$ is the fluorescence intensity at $592 \mathrm{~nm}$ at each concentration of $\mathrm{Al}^{3+}$ added, $F_{\min }$ and $F_{\max }$ are 

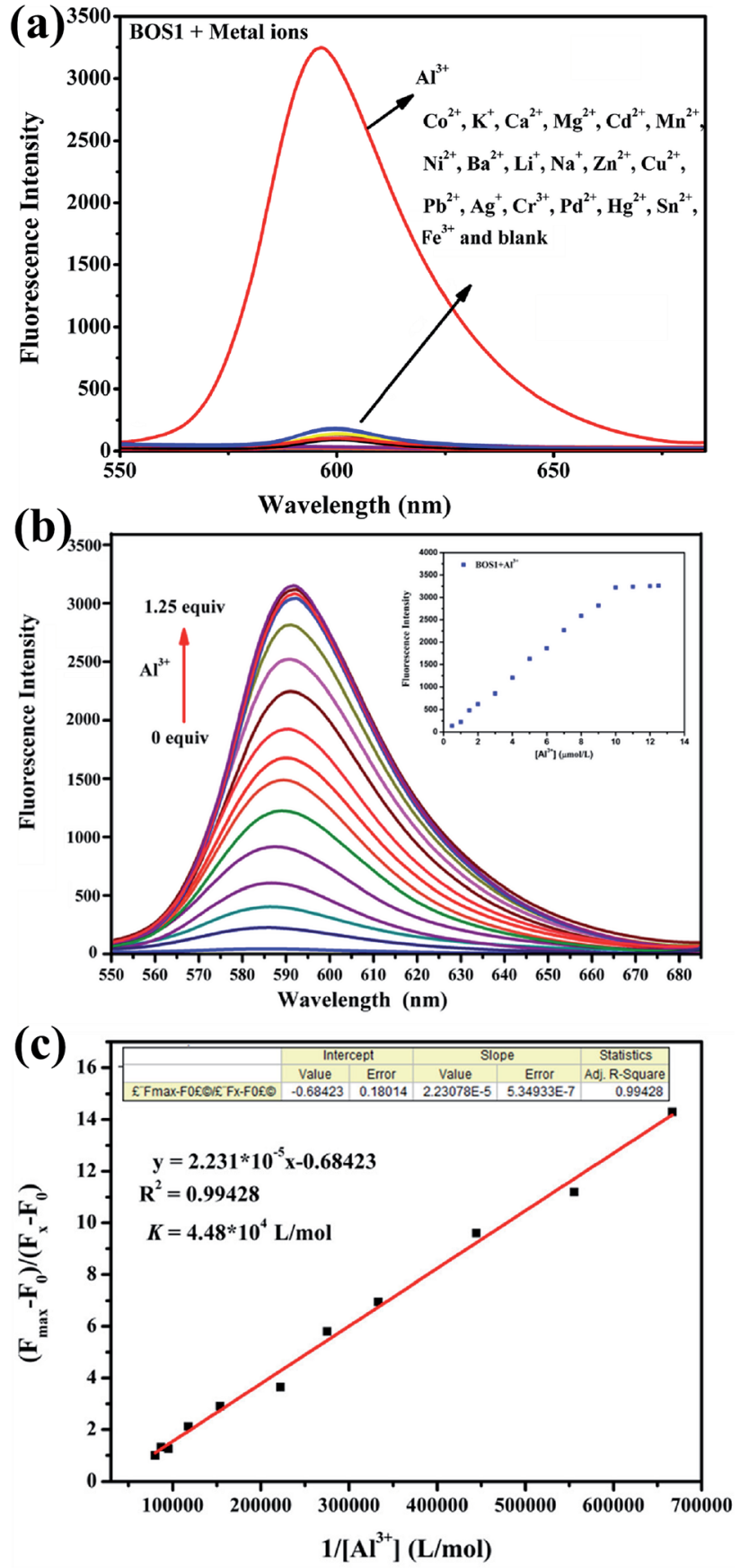

Fig. 1 (a) Fluorescence spectra of BOS1 $(10 \mu \mathrm{M})$ in ethanol-water (1: 9 , v/v, Tris $-\mathrm{HCl}, \mathrm{pH}=7.2$ ) solution upon addition of various metal ions $(10 \mu \mathrm{M})$. (b) Fluorescence spectra of BOS1 $(10 \mu \mathrm{M})$ with the addition of various concentrations of $\mathrm{Al}^{3+}$ ions $(0-12.5 \mu \mathrm{M})$ in ethanolwater (1:9, v/v, Tris- $\mathrm{HCl}, \mathrm{pH}=7.2)$ solution. Inset: changes in the emission intensity at $592 \mathrm{~nm}$. (c) Determination of binding constant of BOS1 with $\mathrm{Al}^{3+}$ using Benesi-Hildebrand equation.

respectively the minimum and maximum fluorescence intensity at $592 \mathrm{~nm}$, thus the intercepts of the lines at $x$-axis were taken as the detection limit of BOS1 $(1.839 \mu \mathrm{M})$ and BOS2 $(1.374 \mu \mathrm{M})$ (Fig. S4†).

The outstanding selectivity to the target detective metal ion over other potentially competing species is crucial for the

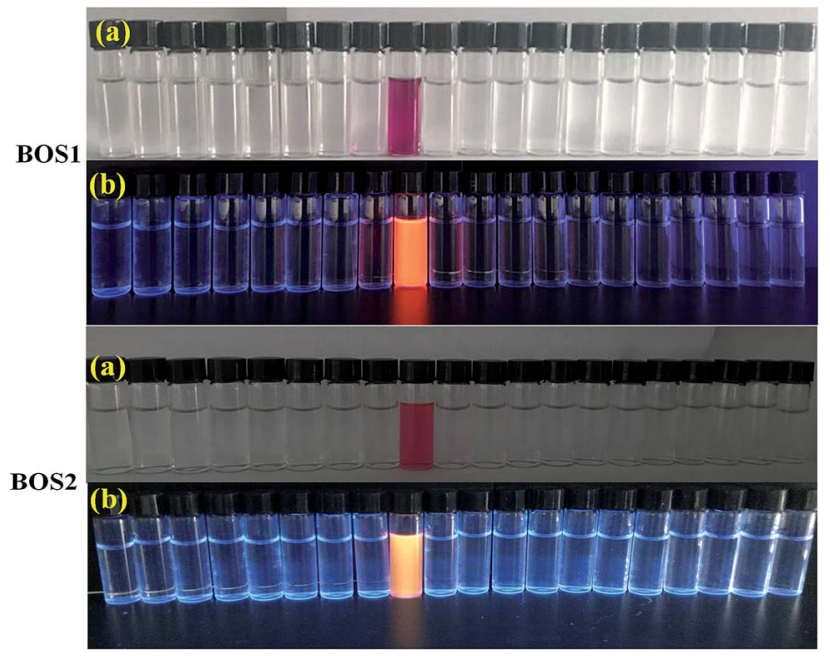

Fig. 2 Pictures of BOS1 and BOS2 as selective naked-eye chemosensors (a) and the visual fluorescence emissions by using a UV lamp $(365 \mathrm{~nm})$ (b) for $\mathrm{Al}^{3+}$. From the left to right: $\mathrm{Li}^{+}, \mathrm{Na}^{+}, \mathrm{K}^{+}, \mathrm{Ag}^{+}, \mathrm{Mg}^{2+}$, $\mathrm{Ca}^{2+}, \mathrm{Ba}^{2+}, \mathrm{Fe}^{3+}, \mathrm{Al}^{3+}, \mathrm{Cr}^{3+}, \mathrm{Sn}^{2+}, \mathrm{Co}^{2+}, \mathrm{Cd}^{2+}, \mathrm{Mn}^{2+}, \mathrm{Ni}^{2+}, \mathrm{Zn}^{2+}, \mathrm{Cu}^{2+}$, $\mathrm{Pb}^{2+}, \mathrm{Pd}^{2+}, \mathrm{Hg}^{2+}$.

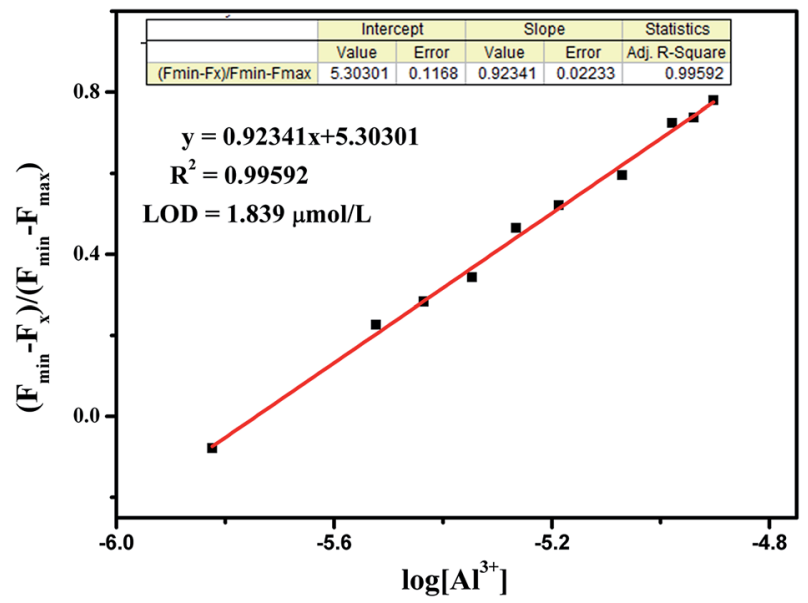

Fig. 3 The plot of $\left(F_{\min }-F_{x}\right) /\left(F_{\min }-F_{\max }\right)$ versus $\log \left[\mathrm{Al}^{3+}\right]$ for the probe BOS1.

application of metal ions sensors. So the fluorescence response of BOS1 $(10 \mu \mathrm{M})$ towards $\mathrm{Al}^{3+}$ ions and other various metal ions in $\mathrm{EtOH} / \mathrm{H}_{2} \mathrm{O}=1 / 9(\mathrm{v} / \mathrm{v}$, Tris- $\mathrm{HCl}, \mathrm{pH}=7.2)$ were investigated. As depicted in Fig. 4, no obvious changes of fluorescence intensity could be detected when 1.0 equiv. metal ions $\left(\mathrm{Co}^{2+}, \mathrm{K}^{+}\right.$, $\mathrm{Ca}^{2+}, \mathrm{Mg}^{2+}, \mathrm{Cd}^{2+}, \mathrm{Mn}^{2+}, \mathrm{Ni}^{2+}, \mathrm{Ba}^{2+}, \mathrm{Li}^{+}, \mathrm{Na}^{+}, \mathrm{Zn}^{2+}, \mathrm{Cu}^{2+}, \mathrm{Pb}^{2+}$, $\mathrm{Ag}^{+}, \mathrm{Cr}^{3+}, \mathrm{Pd}^{2+}, \mathrm{Hg}^{2+}, \mathrm{Sn}^{2+}, \mathrm{Fe}^{3+}$ ) were added into the relevant solution. Conversely, about 100-fold enhancement of emission intensity at $592 \mathrm{~nm}$ appeared obviously in the presence of subsequent 1.0 equiv. $\mathrm{Al}^{3+}$ ions, indicating that the recognition of $\mathrm{Al}^{3+}$ ions by the probe BOS1 is not interfered by other coexisting metal ions. The above facts reveal that the BOS1 shows high selectivity, anti-interference and sensitivity toward $\mathrm{Al}^{3+}$ ions, and could be potentially applied to detect $\mathrm{Al}^{3+}$ ions in complex systems. The similar $\mathrm{Al}^{3+}$ response performances were also observed for the probe BOS2 (Fig. S5†). 


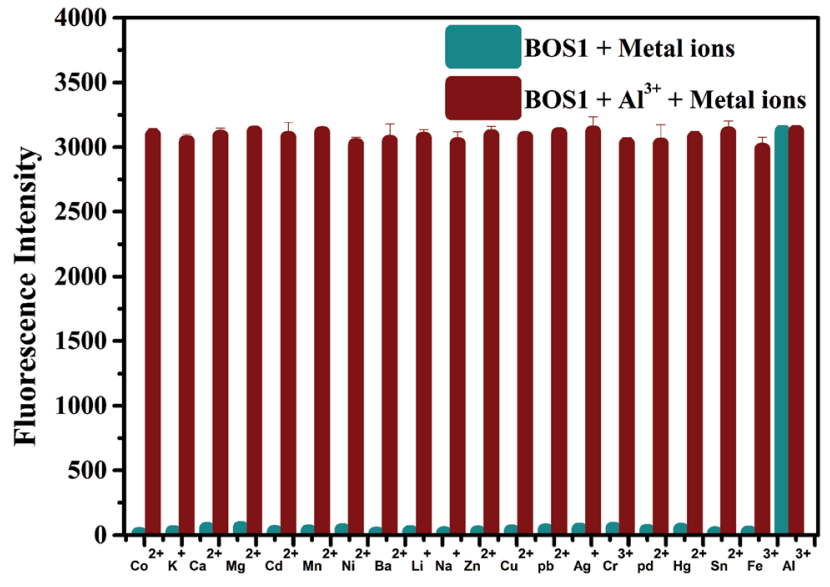

Fig. 4 Fluorescence intensity changes of BOS1 $(10 \mu \mathrm{M})$ upon the addition of various metal ions $(10 \mu \mathrm{M})$ in the presence of $\mathrm{Al}^{3+}(10 \mu \mathrm{M})$ in ethanol-water $(1: 9, \mathrm{v} / \mathrm{v}$, Tris $-\mathrm{HCl}, \mathrm{pH}=7.2)$ solution. The teal bars represent the fluorescence response of BOS1 and metal ions. The dark red bars represent the subsequent addition of $10 \mu \mathrm{M} \mathrm{Al}^{3+}$ to the above solutions.

The UV-vis absorption of the probes $(10 \mu \mathrm{M})$ was also investigated in an ethanol-water $(1: 9, \mathrm{v} / \mathrm{v}$, Tris- $\mathrm{HCl}, \mathrm{pH}=7.2)$ solution. As can be seen in Fig. $5 \mathrm{a}$ and $\mathrm{S} 6, \uparrow$ both the free BOS1 and BOS2 exhibited nearly no absorption bands in the visible region, which may be attributed to their closed spirolactam forms. As expected, a significant enhancement of the absorption at $568 \mathrm{~nm}$ (BOS1) or at $559 \mathrm{~nm}$ (BOS2) was observed in the presence of $\mathrm{Al}^{3+}$ ions, whereas tiny absorption changes occurred when nineteen other metal ions added, respectively. With the increasing concentration of $\mathrm{Al}^{3+}$ ions in the range of $0-100 \mu \mathrm{M}$, the absorption band gradually enhanced, indicating the ringopening form of the rhodamine spirolactam of BOSs. The absorption intensity showed negligible changes with further increasing the concentration of $\mathrm{Al}^{3+}$ (up to $12.5 \mu \mathrm{M}$ ), which suggested the saturated binding behaviours between $\mathrm{Al}^{3+}$ and BOS probes (Fig. 5b and $\mathrm{S} 7 \dagger$ ). The association constant for $\mathrm{Al}^{3+}$ ions was calculated to be $4.39 \times 10^{4} \mathrm{M}^{-1}\left(\right.$ BOS1) and $4.76 \times 10^{4}$ $\mathbf{M}^{-1}$ (BOS2) from the absorption titration curves. Moreover, the dramatical color changes from colorless to peach-red associated with the reaction of probes with $\mathrm{Al}^{3+}$ ions were visually detectable with good selectivity, which indicated that BOS1/BOS2 could successfully serve as "naked-eye" probes for $\mathrm{Al}^{3+}$ detection (Fig. 2).

It is well known that the spirolactam ring of the rhodamine derivative is commonly open in acidic media and shows the fluorescence of rhodamine. Therefore, the optimal $\mathrm{pH}$ conditions for the probes BOS1/BOS2 should be evaluated to affirm their stabilities for potential practical applications. The $\mathrm{pH}$ dependent fluorescence responses of BOS1 and BOS2 in the presence and absence of $\mathrm{Al}^{3+}$ were recorded in the $\mathrm{pH}$ range of 2-12 (Fig. 6 and S9†). For BOS1 system, the fluorescence intensities of both BOS1 and the BOS1- $\mathrm{Al}^{3+}$ species were strong enough when $\mathrm{pH}<4$, which could be due to the ring opening of rhodamine derivatives induced by strong protonation of the tertiary amine-N atom in acid conditions. No obvious emission of free BOS1 was observed when $\mathrm{pH}>5$, while the strong
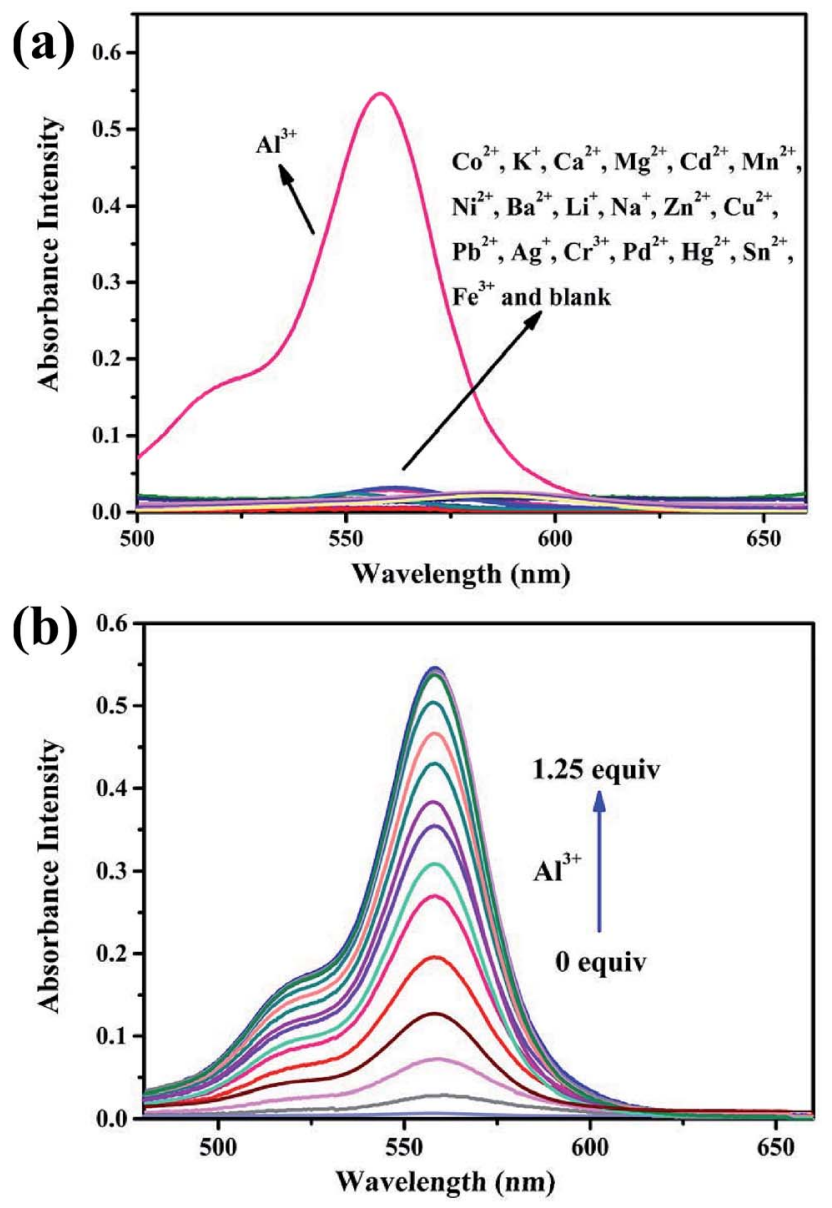

Fig. 5 (a) UV-vis absorption spectra of BOS1 $(10 \mu \mathrm{M})$ in ethanol-water (1: 9, v/v, Tris $-\mathrm{HCl}, \mathrm{pH}=7.2$ ) solution upon addition of various metal ions $(10 \mu \mathrm{M})$. (b) UV-vis absorption spectra of BOS1 $(10 \mu \mathrm{M})$ with the addition of various concentrations of $\mathrm{Al}^{3+}$ ions $(0-12.5 \mu \mathrm{M})$ in ethanolwater (1: 9, v/v, Tris- $\mathrm{HCl}, \mathrm{pH}=7.2)$ solution.

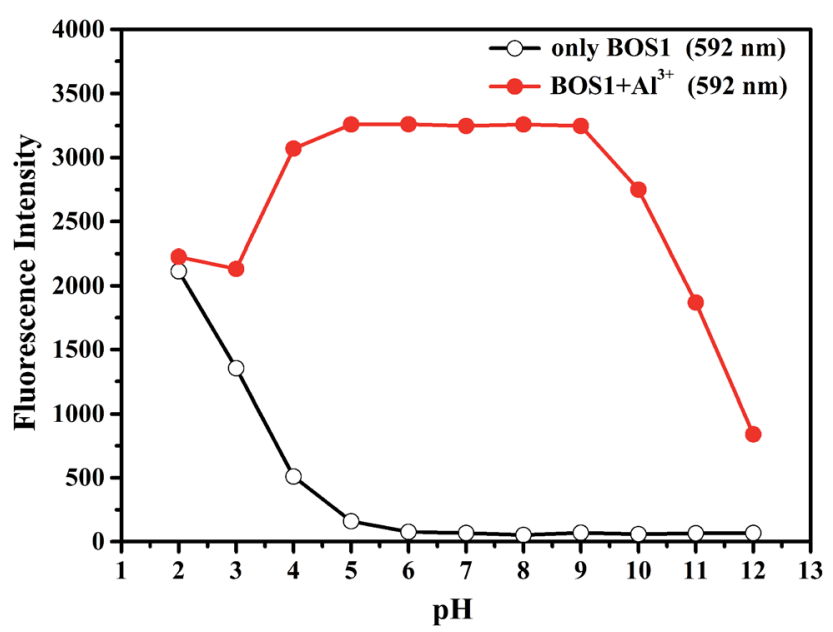

Fig. 6 Effects of $\mathrm{pH}$ on BOS1 $(10 \mu \mathrm{M})$ response to $\mathrm{Al}^{3+}$ (the $\mathrm{pH}$ of solution was adjusted by aqueous solution of $\mathrm{NaOH}(1 \mathrm{M})$ and $\mathrm{HCl}(1 \mathrm{M})$ ). 
fluorescence emissions after the addition of $\mathrm{Al}^{3+}$ within the $\mathrm{pH}$ range of 5-9 were detected, which revealed that the BOS1- $\mathrm{Al}^{3+}$ complex was formed in this $\mathrm{pH}$ region and the BOS1 probe towards $\mathrm{Al}^{3+}$ could work well in such approximate physiological conditions with a low background response. With further increasing the $\mathrm{pH}$ value, the emission intensities were quenched because of the decoordination of $\mathrm{Al}^{3+}$, leading to the formation of $\mathrm{Al}(\mathrm{OH})_{3}$ and the reformation of spirolactam rings. Similar events were also found in the BOS2 system, the BOS2$\mathrm{Al}^{3+}$ species presented the strongest fluorescent responses within an optimal $\mathrm{pH}$ range of 5-9. The suitable $\mathrm{pH}$ response range suggested that no buffer solutions were required for the detection of $\mathrm{Al}^{3+}$, and both BOS1 and BOS2 would provide the potential practical applications in environmental systems or living cells.

In addition, the response time is important to the application of naked-eye detection. So the time dependent fluorescence responses of BOS1 and BOS2 in the presence of $\mathrm{Al}^{3+}$ were carried out in a simulated in vivo environment (ethanol-water $1: 9, \mathrm{v} / \mathrm{v}$, Tris-HCl, $\mathrm{pH}=7.2$ ) at room temperature. As the BOS1/BOS2 interacted with $\mathrm{Al}^{3+}$, the fluorescence intensities of the analysis systems significantly increased to the maximum value within approximately $30 \mathrm{~s}$ for BOS1 (Fig. 7) and $42 \mathrm{~s}$ for BOS2 (Fig. S10 $\dagger$ ). These results show that BOS1 and BOS2 are reliable instantaneously responsive colorimetric sensor for $\mathrm{Al}^{3+}$.

\section{Proposed mechanism for the interactions between probes and $\mathbf{A l}^{3+}$}

According to the results of spectroscopic responses of BOS1/ BOS2 to $\mathrm{Al}^{3+}$, we speculated that the probable binding ways and interaction mechanisms between BOS1/BOS2 and $\mathrm{Al}^{3+}$ were likely due to the chelation-induced ring opening of rhodamine spirolactam (Scheme 2), rather than other possible reactions, which were similar to those reported in previously literatures. ${ }^{40-44}$ That is, the $\mathrm{Al}^{3+}$ ions coordinated to the phenolic hydroxyl $\mathrm{O}$, imino $\mathrm{N}$, benzoylamide $\mathrm{O}$ and $\mathrm{N}$ atoms of the probes

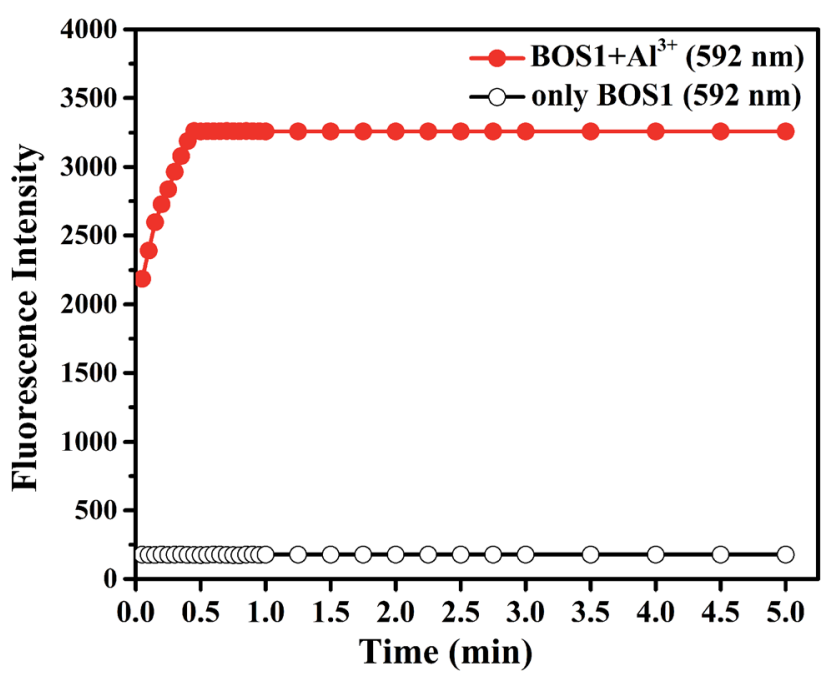

Fig. 7 Effects of time on BOS1 $(10 \mu \mathrm{M})$ response to $\mathrm{Al}^{3+}$ in ethanolwater $(1: 9, \mathrm{v} / \mathrm{v}$, Tris $-\mathrm{HCl}, \mathrm{pH}=7.2)$ solutions. to form conjugated moieties, and the lactam rings of rhodamine were induced to be opened, exhibiting significant fluorescence enhancements.

Binding analysis was further performed to determine the ratio between probes and $\mathrm{Al}^{3+}$ by using the method of continuous variations (Job's plots). As shown in Fig. 8, a maximum fluorescence emission at $592 \mathrm{~nm}$ was observed when the molecular fraction of $\mathrm{Al}^{3+}$ is close to 0.5 , which revealed that the $\mathrm{Al}^{3+}$-chemodosimeter displayed $1: 1$ stoichiometry, and further proved the above-mentioned binding modes.

The binding reversibility of the probe BOS1 was also examined by the EDTA-adding experiments at room temperature. As illustrated in Fig. 9, the absorbance and fluorescence intensities rapidly decreased when EDTA was added to the $\mathrm{Al}^{3+}$-BOS1 system. Meanwhile, the color of the solutions changed from peach-red to colorless. When $\mathrm{Al}^{3+}$ ions were dropwise added into these systems again, the spectral signals were almost completely reproduced and the peach-red solutions appeared again. These reversible processes can be repeated several cycles without significant fluorescence changes (Fig. 9b, inset), indicating that the BOS probes are reversible fluorescence sensors toward $\mathrm{Al}^{3+}$.

\section{Cytotoxicity and fluorescence imaging}

The MTT assays were performed to explore the cytotoxic effects of BOS1, BOS2 and $\mathrm{Al}^{3+}$ according to the reported method..$^{35}$ The relevant data expressed as mean \pm standard deviation were listed in Table $\mathrm{S} 1 \dagger$ and the results were depicted in Fig. 10. The SGC-7901 living cells (human gastric carcinoma cells) viability remained $84.52 \%, 90.38 \%$ and $86.58 \%$ after the treatment of 25 $\mu \mathrm{M}$ probes BOS1, BOS2 and $\mathrm{Al}^{3+}$, respectively, which indicated that all of them were low cytotoxic to cells and suitable for bioimaging.

Fluorescence imaging experiments were conducted in the living cells to further demonstrate the practical applicability of the probes in biological samples. ${ }^{45}$ Fig. 11 presented the fluorescence images of SGC-7901 cells recorded before and after the addition of $\mathrm{Al}^{3+}$. Apparently, free BOS1 and BOS2 probes showed no detectable fluorescence signals in living cells in the absence of $\mathrm{Al}^{3+}$ (Fig. 11a). By contrast, bright fluorescence signals were observed in living cells after incubation with $\mathrm{Al}^{3+}$ (Fig. 11c). Bright-field transmission images of cells treated with probes and target $\mathrm{Al}^{3+}$ ions showed that the cells were viable throughout the imaging experiments (Fig. 11b). The results

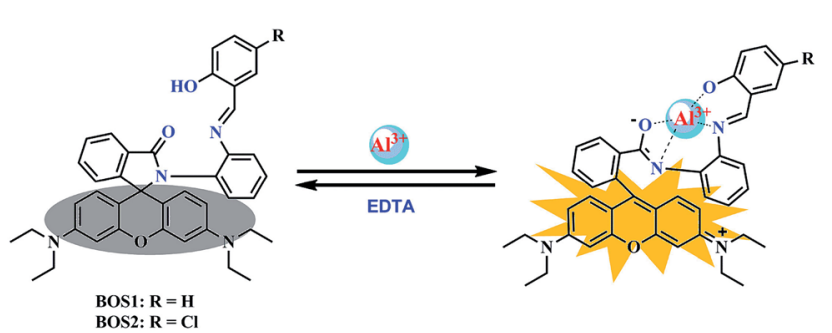

Scheme 2 Proposed mechanisms of the interactions between BOS1/ BOS2 and $\mathrm{Al}^{3+}$ ions. 


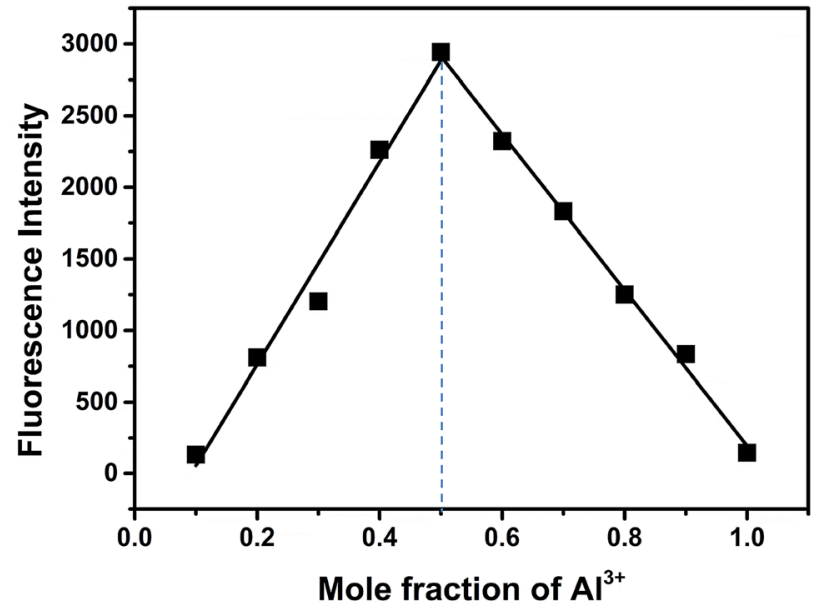

Fig. 8 Job's plot of BOS1 and $\mathrm{Al}^{3+}$ (the total concentration was $10 \mu \mathrm{M}$ ).
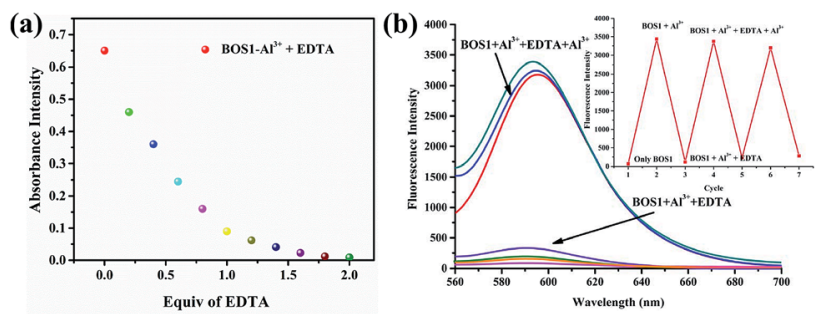

Fig. 9 (a) Absorbance intensity changes at about $558 \mathrm{~nm}$ of BOS1 (10 $\mu \mathrm{M})$ upon the addition of each equiv. of EDTA with the presence of $\mathrm{Al}^{3+}$ in ethanol-water $(1: 9, \mathrm{v} / \mathrm{v}$, Tris $-\mathrm{HCl}, \mathrm{pH}=7.2)$ solution. (b) Fluorescence intensity of BOS1 $\mathrm{Al}^{3+}$ as a function of EDTA concentration in ethanol-water $(1: 9, \mathrm{v} / \mathrm{v}$, Tris $-\mathrm{HCl}, \mathrm{pH}=7.2)$ solution. Inset: central intensity changes of BOS1 for three cycles of the switching processes.

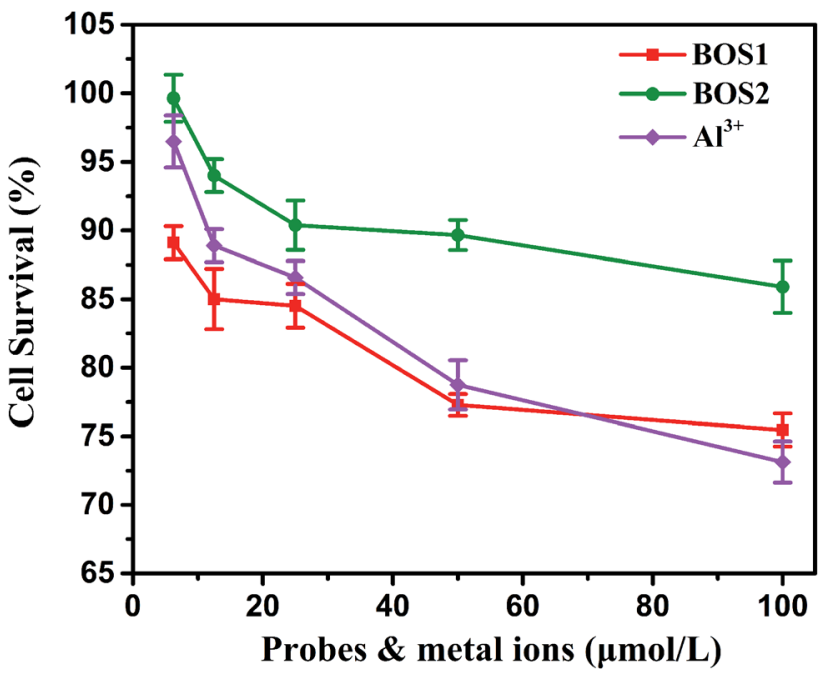

Fig. 10 SGC-7901 living cells viability of BOS1, BOS2 and $\mathrm{Al}^{3+}$ quantified by the MTT assay (mean $\pm S D$ ).

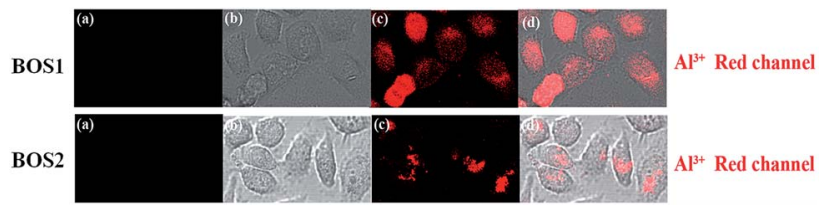

Fig. 11 Probes BOS1 and BOS2 for Al(III) fluorescence images in SGC7901 living cells. Fluorescence images of SGC-7901 cells treated with probes $(20 \mu \mathrm{M})$ in either the absence (a) or the presence (c) of $20 \mu \mathrm{M}$ $\mathrm{Al}^{3+}$ ions for $1 \mathrm{~h}$ at $37^{\circ} \mathrm{C}$. (b) Bright-field image of cells shown in panel. (d) Overlay image of (b) and (c).

suggested that probes BOS1/BOS2 possessed the capacity to readily penetrate the cell membrane and could be applied for in vitro imaging of $\mathrm{Al}^{3+}$ in living cells, and potentially in vivo.

\section{Conclusions}

In summary, two novel rhodamine-based fluorescent probes BOS1 and BOS2 were designed and synthesized. Upon binding with $\mathrm{Al}^{3+}$, dramatic fluorescence and absorption enhancements were observed due to the formation of ring-opening of rhodamine species, showing distinct color changes and switch-on fluorescence. The probes displayed high selectivity, low detection limit, and fast response to $\mathrm{Al}^{3+}$ ions over other examined metal ions in ethanol-water system. Moreover, we have demonstrated their biological application by fluorescence imaging intracellular $\mathrm{Al}^{3+}$ in SGC-7901 living cells. We expect that the chemosensors would help to promote the studies of $\mathrm{Al}^{3+}$ in complex biological systems.

\section{Conflicts of interest}

There are no conflicts to declare.

\section{Acknowledgements}

This work was supported by the National Natural Science Foundation of China (Grant No. 21703135 and 21803042), the Natural Science Foundation of the Department of Education of Shaanxi Province (17JS034), the Outstanding Young Talents Fund of University in Shaanxi Province (18SKY001) and the Natural Science Foundation of Shangluo University (Nos. gz201836 and 17sky028).

\section{References}

1 Y. K. Jang, U. C. Nam, H. L. Kwon, I. H. Hwang and C. Kim, Dyes Pigm., 2013, 99, 6-13.

2 M. Aznar, C. Domeño, C. Nerín and O. Bosetti, Dyes Pigm., 2015, 114, 85-92.

3 J. Barceló and C. Poschenrieder, Environ. Exp. Bot., 2002, 48, 75-92.

4 A. Guo, R. Zhu, Y. Ren, J. Dong and L. Feng, Spectrochim. Acta, Part A, 2016, 153, 530-534.

5 M. Braungart, W. McDonough and A. Bollinger, J. Cleaner Prod., 2007, 15, 1337-1348. 
6 M. Riaz, L. Yan, X. Wu, S. Hussain, O. Aziz and C. Jiang, Ecotoxicol. Environ. Saf., 2018, 165, 25-35.

7 T. Anand, S. K. Ashok Kumar and S. K. Sahoo, Spectrochim. Acta, Part A, 2018, 204, 105-112.

8 M. Adrees, S. Ali, M. Rizwan, M. Zia-Ur-Rehman, M. Ibrahim, F. Abbas, M. Farid, M. F. Qayyum and M. K. Irshad, Ecotoxicol. Environ. Saf., 2015, 119, 186-197.

9 P. M. Bortoli, C. Alves, E. Costa, A. P. Vanin, J. R. Sofiatti, D. P. Siqueira, R. M. Dallago, H. Treichel, G. Vargas and R. R. Kaizer, J. Inorg. Biochem., 2018, 181, 104-110.

10 A. Gal-Moscovici and M. M. Popovtzer, Nephrol., Dial., Transplant., 2002, 17, 620-624.

11 D. B. Mathiyazahan, A. J. Thenmozhi and T. Manivasagam, J. Funct. Foods, 2015, 16, 423-435.

12 J. Roszak, K. Domeradzka-Gajda, A. Smok-Pieniążek, A. Kozajda, S. Spryszyńska, J. Grobelny, E. Tomaszewska, K. Ranoszek-Soliwoda, M. Cieślak, D. Puchowicz and M. Stępnik, Toxicol. In Vitro, 2017, 45, 181-193.

13 X. Feng, Z. Baojie and L. E. E. Chery, J. Environ. Sci., 2007, 20, 907-914.

14 I. Juranović-Cindrić, M. Zeiner, A. Starčević, Z. Liber, G. Rusak, M. Idžojtić and G. Stingeder, J. Trace Elem. Med. Biol., 2018, 48, 190-195.

15 V. Kraft, W. Weber, M. Grützke, M. Winter and S. Nowak, RSC Adv., 2015, 5, 80150-80157.

16 S. Gui, Y. Huang, F. Hu, Y. Jin, G. Zhang, L. Yan, D. Zhang and R. Zhao, Anal. Chem., 2015, 87, 1470-1474.

17 J. Zhang, B. Xing, J. Song, F. Zhang, C. Nie, L. Jiao, L. Liu, F. Lv and S. Wang, Anal. Chem., 2014, 86, 346-350.

18 J. Wang, W. Lin and W. Li, Chem.-Eur. J., 2012, 18, 1362913632.

19 L. Yuan, W. Lin, K. Zheng and S. Zhu, Acc. Chem. Res., 2013, 46, 1462-1473.

20 L. Feng, C. Zhu, H. Yuan, L. Liu, F. Lv and S. Wang, Chem. Soc. Rev., 2013, 42, 6620-6633.

21 X.-l. Yue, Z.-Q. Wang, C.-R. Li and Z.-Y. Yang, Tetrahedron Lett., 2017, 58, 4532-4537.

22 R. Purkait, C. Patra, A. D. Mahapatra, D. Chattopadhyay and C. Sinha, Sens. Actuators, B, 2018, 257, 545-552.

23 R. Alam, R. Bhowmick, A. S. M. Islam, A. katarkar, K. Chaudhuri and M. Ali, New J. Chem., 2017, 41, 8359-8369.

24 H. N. Kim, M. H. Lee, H. J. Kim, J. S. Kim and J. Yoon, Chem. Soc. Rev., 2008, 37, 1465-1472.

25 S. Ma, Z. Yang, M. She, W. Sun, B. Yin, P. Liu, S. Zhang and J. Li, Dyes Pigm., 2015, 115, 120-126.
26 M. Wang, F. Yan, Y. Zou, L. Chen, N. Yang and X. Zhou, Sens. Actuators, B, 2014, 192, 512-521.

27 X. Chen, T. Pradhan, F. Wang, J. S. Kim and J. Yoon, Chem. Rev., 2012, 112, 1910-1956.

28 X. Xiong, F. Song, J. Wang, Y. Zhang, Y. Xue, L. Sun, N. Jiang, P. Gao, L. Tian and X. Peng, J. Am. Chem. Soc., 2014, 136, 9590-9597.

29 J. W. Yoon, M. J. Chang, S. Hong and M. H. Lee, Tetrahedron Lett., 2017, 58, 3887-3893.

30 Z. Yan, G. Wei, S. Guang, M. Xu, X. Ren, R. Wu, G. Zhao, F. Ke and H. Xu, Dyes Pigm., 2018, 159, 542-550.

31 Y. M. Yang, Q. Zhao, W. Feng and F. Y. Li, Chem. Rev., 2012, 113, 192-270.

32 X. Gan, W. Li, C. Li, Z. Wu, D. Liu, B. Huang, H. Zhou and Y. Tian, Sens. Actuators, B, 2017, 239, 642-651.

33 S. Sinha, R. R. Koner, S. Kumar, J. Mathew, P. V. Monisha, I. Kazia and S. Ghosh, RSC Adv., 2013, 3, 345-351.

34 A. Gupta and N. Kumar, RSC Adv., 2016, 6, 106413-106434. 35 M. Maszewska, J. Leclaire, M. Cieslak, B. Nawrot, A. Okruszek, A.-M. Caminade and J.-P. Majoral, Oligonucleotides, 2003, 13, 193-205.

36 L. Tang, F. Li, M. Liu and R. Nandhakumar, Spectrochim. Acta, Part A, 2011, 78, 1168-1172.

37 L. K. Kumawat, N. Mergu, M. Asif and V. K. Gupta, Sens. Actuators, B, 2016, 231, 847-859.

38 A. Caballero, R. Martínez, V. Lloveras, I. Ratera, J. VidalGancedo, K. Wurst, A. Tárraga, P. Molina and J. Veciana, J. Am. Chem. Soc., 2005, 127, 15666-15667.

39 J. Wang, L. Long, D. Xie and X. Song, Sens. Actuators, B, 2013, 177, 27-33.

40 V. Luxami, Renukamal, K. Paul and S. Kumar, RSC Adv., 2013, 3, 9189-9192.

41 M. Beija, C. A. M. Afonso and J. M. G. Martinho, Chem. Soc. Rev., 2009, 38, 2410-2433.

42 E. M. Nolan and S. J. Lippard, Chem. Rev., 2008, 108, 34433480 .

43 H.-S. Kim, S. Angupillai and Y.-A. Son, Sens. Actuators, B, 2016, 222, 447-458.

44 K. Boonkitpatarakul, J. Wang, N. Niamnont, B. Liu, L. McDonald, Y. Pang and M. Sukwattanasinitt, ACS Sens., 2016, 1, 144-150.

45 L. Yuan, W. Lin, Y. Yang and H. Chen, J. Am. Chem. Soc., 2012, 134, 1200-1211. 